Atmos. Chem. Phys. Discuss., doi:10.5194/acp-2016-1082, 2016

\title{
Widespread persistent polar stratospheric ice clouds in the Arctic
}

\author{
Christiane Voigt ${ }^{1,2}$, Andreas Dörnbrack ${ }^{1}$, Martin Wirth ${ }^{1}$, Silke M. Groß ${ }^{1}$, Robert Baumann ${ }^{1}$, \\ Benedikt Ehard ${ }^{1}$, Michael C. Pitts ${ }^{3}$, Lamont R. Poole ${ }^{4}$, Björn-Martin Sinnhuber ${ }^{5}$, Hermann \\ Oelhaf $^{5}$
}

$5 \quad{ }^{1}$ Institute of Atmospheric Physics, Deutsches Zentrum für Luft- und Raumfahrt (DLR), Oberpfaffenhofen, 82234, Germany.

${ }^{2}$ Institute of Atmospheric Physics, Johannes Gutenberg-University, Mainz, 55881, Germany.

${ }^{3}$ NASA Langley Research Center, Hampton, VA, 23681, USA.

${ }^{4}$ Science Systems and Applications, Incorporated, Hampton, VA, 23681, USA.

10 Institute for Meteorology and Climate Research, Karlsruhe Institute of Technology, Karlsruhe, 76344, Germany.

Correspondence to: Christiane Voigt (Christiane.Voigt@dlr.de)

Abstract. Despite a general decline in ozone depleting substances in the stratosphere due to the multinational commitment to substantially reduce the emissions of their precursors, the magnitude of Arctic polar ozone loss has not decreased in recent years. Thus new observations at cold conditions can help to enhance our knowledge of polar stratospheric cloud (PSC) formation and life cycle which is of relevance for Arctic ozone loss. In the unique winter 2015/16, cold and persistent areas with temperatures below the ice frost point $\mathrm{T}_{\text {ice }}$ developed in the Arctic stratosphere, caused by reduced perturbations of the polar vortex through planetary waves. Due to these extreme conditions, unprecedented and widespread ice PSCs formed and persisted for more than a month in the Arctic. These ice PSCs were repeatedly detected by lidars on the CALIPSO satellite and on the high altitude long range research aircraft HALO. A new lower threshold of the backscatter ratio ${ }^{-1}$ of 0.3 for ice PSCs derived from high-resolution lidar measurements at $532 \mathrm{~nm}$ wavelength leads to enhanced ice PSC coverage compared to previous analysis. 
Atmos. Chem. Phys. Discuss., doi:10.5194/acp-2016-1082, 2016

The ice PSCs were generally surrounded by nitric acid trihydrate (NAT) and supercooled ternary solution (STS) clouds. By combining optical PSC data and trajectory analysis, we investigate ice formation pathways. In addition to ice nucleation in $\mathrm{STS}_{\mathrm{m}}$ with meteoric dust, we find that ice nucleation on preexisting NAT may play an important role in polar winter. Persistent synoptic-scale Arctic ice PSCs have not been observed so far. Hence, ice PSCs are a sensitive marker for cold stratospheric winter temperatures modulated by natural variability and climate change.

\section{Introduction}

While widespread ice PSCs commonly occur in the Antarctic winter stratosphere (Solomon et al., 1986), synoptic-scale ice PSCs extending over several thousand $\mathrm{km}^{2}$ have rarely been observed in the Arctic (Pitts et al., 2011). Even since enhanced observational coverage of the polar regions by the space-borne Cloud-Aerosol Lidar with Orthogonal Polarization CALIOP instrument (Pitts et al., 2009; Pitts et al., 2011) onboard the CALIPSO satellite, widespread ice PSCs were detected in the Arctic only once and persisted about a day (Engel et al., 2013). Generally Arctic stratospheric temperatures are above the ice frost point $\mathrm{T}_{\text {ice }}$ (Murphy and Koop, 2005) on synoptic scales and hence limit the formation of extended ice PSCs. The reason for the warmer temperatures in the Arctic compared to the Antarctic is a stronger landocean contrast in the northern hemisphere, supporting the generation of planetary waves, which disturb and hence weaken the polar vortex due to inmixing of warmer mid-latitude air (Solomon, 2004). In addition, radiative heating of the displaced and elongated vortex contributes to warmer Arctic vortex temperatures.

45 At cold conditions near and below $\mathrm{T}_{\text {ice, }}$ ice PSCs can exist, while other PSC types prevail at higher temperatures. These can contain solid nitric acid trihydrate (NAT) particles (Voigt et al., 2000; Fahey et al., 2001) particles, supercooled ternary solution droplets (STS) (Dye et al., 1992; Schreiner et al., 1999) and mixtures of both (Schreiner et al., 2002; Pitts et al., 2009). Lidar observations led to a cloud 
Atmos. Chem. Phys. Discuss., doi:10.5194/acp-2016-1082, 2016

classification based on the optical properties of solid or liquid PSC particles (Toon et al., 2000). PSCs with depolarizations below 0.04 at $532 \mathrm{~nm}$ wavelength were classified as STS (Pitts et al., 2009). PSCs with higher depolarization were labelled MIX1 and MIX2, probably NAT clouds with lower or higher NAT particle number densities, respectively, and some amounts of STS. Finally depolarizing PSCs with backscatter ratios above 5 were classified as ice. Later studies (Pitts et al., 2011; Pitts et al., 2013) led to an even more detailed differentiation of PSC types.

Due to their large surface areas, ice PSCs very efficiently activate halogen compounds (Hanson and Ravishankara, 1992) and hence are responsible for a major fraction of polar ozone loss in the Antarctic (Toon et al., 1989). Processing of halogenated reservoir gases on PSC particles leads to a release of unstable chlorine and bromine species, which become activated by sunlight in polar spring and effectively destroy ozone in catalytic cycles (Farman et al., 1985; Crutzen and Arnold, 1986). Ozone depletion is stopped, when the activated chlorine and bromine species react with nitrogen dioxide to reform stable reservoirs. In the absence of ice, other PSC types may provide surfaces necessary for heterogeneous chlorine processing (Grooß et al., 2005; Manney et al., 2011; Drdla and Müller, 2012). E.g. in the Arctic winters 2009/10 and 2010/11 (Manney et al., 2011; Sinnhuber et al., 2011; von Hobe et al., 2013), polar ozone loss may have been driven to a large extent by STS aerosol (Wohltmann et al., 2013) and NAT (Nakajima et al., 2016).

Stratospheric ice may form homogeneously in liquid STS aerosol or heterogeneously by the aid of solid particles (Toon et al., 1989; Peter, 1997; Zondlo et al., 2000). In the Arctic, homogeneous ice nucleation may occur at high cooling rates in localized mountain wave events (Dörnbrack et al., 2002). However, nucleation rates (Koop et al., 2000) generally are too low to allow for homogeneous ice nucleation on synoptic scales. Thus, heterogeneous ice nucleation (Engel et al., 2013) aided by small scale temperature fluctuations in STS with meteoric dust (Cziczo et al., 2001; Voigt et al., 2005; Curtius et al., 2005; Weigel et al., 2014) were required to explain the formation of the synoptic-scale ice PSC observed on 18 January 2010 in the Arctic. 
Atmos. Chem. Phys. Discuss., doi:10.5194/acp-2016-1082, 2016

2 Extremely cold Arctic stratospheric winter temperatures in 2015/2016 caused by low planetary wave activity

The temperature development in the Arctic winter stratosphere is strongly influenced by planetary wave activity. Both the excitation of planetary waves in the troposphere and their vertical propagation to the stratosphere were low in the early northern hemispheric 2015 winter as suggested from meteorological data by the European Centre for Medium-Range Weather Forecasts (ECMWF) numerical weather prediction model. A strong tropical tropospheric temperature anomaly reinforced a strong meridional temperature gradient from the tropics to the poles and led to adverse conditions for the propagation of planetary waves. Weak planetary wave activity measured as low meridional heat flux enforced the formation of a strong and stable polar vortex (Matthias et al., 2016) and hence caused extremely low polar cap temperatures in the Arctic winter 2015/16.

Therefore, Arctic stratospheric temperatures decreased dramatically and the minimum temperature $\mathrm{T}_{\min }$ (at $\varphi>65^{\circ} \mathrm{N}$ ) continuously dropped below $\mathrm{T}_{\text {ice }}$ from late December 2015 till end of January 2016 (see Fig. 1). Three minor stratospheric warmings (Manney and Lawrence, 2016) influenced the vortex and led to warmer conditions in a coherent but slightly displaced polar vortex in February 2016, with temperatures still below the NAT stability temperature $\mathrm{T}_{\mathrm{NAT}}$ (Hanson and Mauersberger, 1988). Then, the final stratospheric warming (Manney and Lawrence, 2016) resulted in a split of the vortex by mid-March and the subsequent dissipation of the vortices associated with a temperature increase of more than $20 \mathrm{~K}$ at $30 \mathrm{hPa}$ in a few days.

Within the first cold phase, unprecedented minimum temperatures down to $179 \mathrm{~K}$ were detected, lower than each single minimum temperature within the 36-years climatological record of the ERA interim data set (see Fig. 1A), which comprise the latest global ECMWF reanalysis data from 1989 to present at a resolution of $1^{\circ} \times 1^{\circ}$ (Dee et al., 2011). $T_{\min }$ was continuously below $T_{\text {ice }}$ for about one month, longer than ever before in the Arctic ERA interim data record. To investigate the effect of higher horizontal resolution of the meteorological data on temperatures, we also show the operational IFS analysis at $0.25^{\circ} \times 0.25^{\circ}$ 
Atmos. Chem. Phys. Discuss., doi:10.5194/acp-2016-1082, 2016

resolution (thin black line in Fig. 1A). The higher resolution IFS analysis shows lower temperatures (1 to $3 \mathrm{~K}$ ) at the beginning of the cold phase compared to the lower resolution data (red line in Fig. 1A). Enhanced mesoscale gravity wave activity in December and early January 2016 could have caused this temperature decrease and is better covered in the higher resolution data.

At $30 \mathrm{hPa}$, the area with $\mathrm{T}<\mathrm{T}_{\text {ice }}$ extended over regions up to $3.6 \times 10^{6} \mathrm{~km}^{2}$ (Fig. 1), and reached up to 4.9 $\times 10^{6} \mathrm{~km}^{2}$ at $50 \mathrm{hPa}$. From 18 January till the end of the month, the area with $\mathrm{T}<\mathrm{T}_{\text {ice }}$ was continuously more than one order of magnitude larger than its 36-years average and larger than the maximum of the 36-years ERA record. These extremely cold stratospheric winter conditions set the stage for excessive synoptic-scale PSC formation in the Arctic winter 2015/16.

\section{Unprecedented synoptic-scale ice PSCs persisted over a month in the Arctic winter 2015/16}

For the first time in the observational record, persistent ice PSC occurrence was measured with the 110 CALIOP lidar onboard the CALIPSO satellite (Fig. 1D) throughout the Arctic winter from December 2015 to late January 2016. Ice PSCs were observed at altitudes between 15 and $25 \mathrm{~km}$ inside the Arctic vortex during the period with extremely cold temperatures in the ERA interim data set (Dörnbrack et al., 2016). The duration and the maximum extension of ice PSCs of $2 \times 10^{6} \mathrm{~km}^{2}$ (near $21.6 \mathrm{~km}$ or $~ 30 \mathrm{hPa}$ ) derived from CALIPSO in early winter roughly agrees with the possible ice area $A_{\text {ice }}$ derived from ERA interim data, taking into account different spatial coverages of the two data sets. This suggests that ice PSCs nucleate as soon as temperatures decrease below $T_{\text {ice }}$, possibly via heterogeneous nucleation. A decrease in water vapor concentrations due to dehydration inside the vortex may explain larger differences in late winter. The extension of ice PSCs is largest in the Arctic winter 2015/16 and greater than ever in the 8 years CALIPSO data record. Summarized, we find strong evidence for the unprecedented existence of widespread ice PSCs in the Arctic.

\section{High-resolution lidar measurements of ice PSCs during the POLSTRACC/SALSA/GW-CYCLE campaign}


Atmos. Chem. Phys. Discuss., doi:10.5194/acp-2016-1082, 2016

From 7 December 2015 till 20 March 2016, the international field campaign POLSTRACC/GWCYCLE/SALSA was conducted with the high-altitude and long-range Gulfstream G550 research aircraft HALO out of Oberpfaffenhofen, Germany $\left(48^{\circ} \mathrm{N}, 11^{\circ} \mathrm{E}\right)$ and Kiruna, Sweden $\left(68^{\circ} \mathrm{N}, 20^{\circ} \mathrm{E}\right)$. While the POLSTRACC (Polar Stratosphere in a Changing Climate) campaign focusses on polar stratospheric chemistry and physics, GW-CYCLE (Gravity Wave Life Cycle) investigates the dispersion of gravity waves from the troposphere to the mesosphere using also observations on the DLR research aircraft Falcon. Finally, SALSA (Seasonality of Air mass transport and origin in the Lowermost Stratosphere using the HALO Aircraft) investigates transport and mixing of air masses in the lower stratosphere region in polar winter/spring conditions.

The campaign's location and season were chosen to allow for aircraft measurements inside the Arctic polar vortex in winter 2015/2016. With a range of more than $8000 \mathrm{~km}$ and a ceiling altitude of $15 \mathrm{~km}$ HALO is perfectly suited to measure the composition of the vortex up to the North Pole. PSC abundance above HALO flight altitudes was detected with the high spectral resolution light detection and ranging lidar instrument WALES (Wirth et al., 2010; Groß et al., 2014). In addition, the lower part of the polar vortex was probed with the combined in-situ and remote sensing payload of HALO in order to characterize the chemical evolution of polar vortex air and to provide specific in-situ PSC information.

For particle detection, the WALES lidar as configured during POLSTRACC, has backscatter channels at $532 \mathrm{~nm}$ and $1064 \mathrm{~nm}$ wavelengths and additionally a high spectral resolution lidar (HSRL) channel and a depolarization channel at $532 \mathrm{~nm}$ wavelength. The HSRL capability allows the retrieval of the extinction corrected backscatter coefficient of clouds at $532 \mathrm{~nm}$ without assumptions about the phase function of the particles (Esselborn, 2008). Linear particle depolarization is derived from volume polarization data and backscatter ratio, following the method outlined by Freudenthaler et al. (2009). The relative sensitivity of the two polarized channels is recalibrated regularly during flight to guarantee reliable depolarization values. 
Atmos. Chem. Phys. Discuss., doi:10.5194/acp-2016-1082, 2016

PSCs were detected with the WALES lidar on all flights inside the vortex between 22 January and 2 February 2016. A synoptic PSC measured on 22 January 2016 during a flight from Kiruna to the northern tip of Greenland and back is shown in Fig. 2. The lidar observations from aircraft cruising near $14 \mathrm{~km}$ altitude allow for an extraordinary high data resolution compared to the lidar on the CALIPSO satellite travelling at an orbit near $700 \mathrm{~km}$. The PSC extended between 16 and $25 \mathrm{~km}$ altitude over a horizontal distance of $1400 \mathrm{~km}$. It was continuously observed within in the Arctic vortex from $72^{\circ} \mathrm{N}$ to the outermost return point at $86^{\circ} \mathrm{N}$.

\section{New classification of ice PSCs}

From the co-located measurements of particle backscatter ratio and depolarization ratio, a classification into different PSC types is possible (e.g. Toon et al., 2000; Pitts et al., 2009). Figure 3 shows the joint histogram of backscatter ratio and particle depolarization for the cloud from Fig. 2. Overlaid are the regions with correspond to different PSC types following Pitts et al. (2011) with the modification that the sub-classification of MIX2 into MIX2-enhanced and normal MIX2 is dropped and the 1/R limit for ice was set to 0.3 instead of 0.2 . Without the latter change a substantial part of the branch connecting STS and fully developed ice clouds (lower right branch in Fig. 3) would have been counted as NAT/STS mixture (MIX2) instead of ice, which is the more obvious interpretation given the form of the joint histogram.

The new classification has been applied to the PSC observations in Fig. 2C. Polar stratospheric ice clouds (red areas in Fig. 2C) were detected in a cloud layer with a vertical thickness up to $6 \mathrm{~km}$ over distances of several hundred km. The synoptic-scale ice PSC was observed when temperatures decrease below $\mathrm{T}_{\text {ice }}$ (black line in Fig. 2C) confirming the validity of the new classification. In the northern part of the cloud, the ice PSC was embedded in NAT cloud layers extending above the ice PSC (yellow and green). Within the ice PSC, NAT is masked by the higher optical signal from ice, but may be present. At the bottom of the PSC, a layer of larger sedimenting NAT particles was observed, as also derived from the lidar ratio. In 
Atmos. Chem. Phys. Discuss., doi:10.5194/acp-2016-1082, 2016

addition, the southernmost part of the PSC consisted of non-depolarizing liquid STS droplets (blue). The STS layer extended below the ice and was connected to the ice region. Meteoric inclusions could be present in the STS particles.

\section{Temperature histories of the back trajectories starting the PSC}

To investigate ice formation in the Arctic winter 2015/16, we performed trajectory calculations using the Hybrid Single-Particle Lagrangian Integrated Trajectory dispersion model HYSPLIT (Draxler, 1998) with hourly ECMWF forecast data at $0.25^{\circ} \times 0.25^{\circ}$ resolution as meteorological input. The HALO flight track and ECMWF temperatures at $30 \mathrm{hPa}$ on 22 January 2016 are shown in Fig. 4. We calculated backwardtrajectories starting in the PSC observations every $2 \mathrm{~min}$ at $30 \mathrm{hPa}$ near $21.6 \mathrm{~km}$ altitude to analyze ice formation. Further we performed sensitivity studies at higher and lower altitudes (19, 21 and $23 \mathrm{~km}$ ) to account for particle sedimentation, which is not included in the simplified trajectory calculations shown here. As a rough estimate, a 10- $\mu \mathrm{m}$ sized ice crystal sediments about $1 \mathrm{~km}$ in a day (Fahey et al., 2001). For aspherical particles the sedimentation rates are even lower (Woiwode et al., 2014; Weigel et al., 2015), hence our simplified calculations cover the altitude range of sedimenting PSC particles.

Typical backward-trajectories starting in the observed ice PSC every 15 min between 11:20 to 11:50 and 14:40 to 15:10 UT are shown as white (A) or colored lines (B, C) in Fig. 4. The trajectories' starting points are marked by white hexagons in the lidar PSC observation in Fig. 2. The trajectories' temperatures decrease below $\mathrm{T}_{\mathrm{NAT}}$ about one day, and below $\mathrm{T}_{\text {ice }}$ about $12 \mathrm{~h}$ prior to the observations, hence allow for ice formation. In contrast, a typical NAT trajectory (black line in Fig. 4) starting in the NAT layer (black square in Fig. 2) circulates within the inner vortex at temperatures below $188 \mathrm{~K}$ for 10 days and stays above $T_{\text {ice, }}$ indicating that ice did not nucleate. Furthermore, the gray STS trajectory (gray circle in Fig. 2) reveals higher temperatures and never decreases below $\mathrm{T}_{\mathrm{ice}}+2 \mathrm{~K}$. Interestingly, the trajectories starting in the different PSC layers within a single synoptic-scale PSC show different temperature histories and hence can be used for a detailed and comprehensive investigation of ice PSC formation. 
Atmos. Chem. Phys. Discuss., doi:10.5194/acp-2016-1082, 2016 dust

Based on the trajectory calculations and the histogram plot of optical PSC particles (Fig. 3), we suggest different parts of the ice PSC have different nucleation mechanisms. The upper and northernmost fraction of the ice PSC observed on 22 January 2016 had potentially nucleated on pre-existing NAT particles. 10days trajectories indicate that the air masses slowly cooled down about 5 days and again one day prior to the observations. Hence, NAT particles had time to grow for at least a day, potentially longer. CALIPSO observations consistently indicate the presence of NAT clouds from December 2015 to January 2016. NAT nucleation rates on meteoric dust (Voigt et al., 2005; Grooß et al., 2005; Hoyle et al., 2013) may explain the formation of NAT PSCs within a day.

Half a day prior to the observation, the ice trajectories were slowly lifted by $~ 2 \mathrm{~km}$ above Greenland and cooled down to temperatures below $\mathrm{T}_{\text {ice }}$ (Fig. 4B) suggesting a moderate influence of the orography on stratospheric air (Carslaw et al., 2002). The influence of the orography decreases to the north, when trajectories pass aside of Greenland. Cooling rates $<0.5 \mathrm{~K} / \mathrm{h}$ reveal slow synoptic cooling at large scales, significantly lower than the cooling rates of several $\mathrm{K} / \mathrm{h}$ observed in mountain wave events (Luo et al., 2003) and therefore do not allow for homogeneous ice nucleation. Still, mainly in the southern part of the ice cloud, which is embedded in STS, heterogeneous ice nucleation in liquid $\mathrm{STS}_{\mathrm{m}}$ with meteoric material as suggested by Engel et al. (2013) could potentially explain a fraction of the ice PSCs. Here, the trajectories pass directly above Greenland and the effect of small-scale temperature fluctuations may increase. The southern and lower part of the ice PSC is embedded in STS. In Fig. 3 it represents the ice branch on the right with high backscatter ratios. The formation process of this part of the ice cloud is marked by the arrow indicating the STSm - ice transition. In addition, a second distinct ice branch with high depolarization and lower backscatter ratios clearly separated from the other ice branch is shown in Fig. 3. This part of the cloud is embedded in NAT and trajectories pass more to the north at slightly higher altitudes with moderate influence of orography. This fraction of the ice PSC could be explained by 
Atmos. Chem. Phys. Discuss., doi:10.5194/acp-2016-1082, 2016 expand this idea below.

The NAT crystal consists of $1 \mathrm{HNO}_{3} \times 3 \mathrm{H}_{2} \mathrm{O}$ molecules and exists in $\alpha-\mathrm{NAT}$ or $\beta-\mathrm{NAT}$ crystal structure (Iannarelli and Rossi, 2015). Compared to liquid aerosol or meteoric particles, the NAT crystal structure and grid size is more similar to that of ice, and therefore NAT readily nucleates on ice (Iannarelli and Rossi, 2015) as observed in laboratory experiments (Hanson and Mauersberger, 1988; Gao et al., 2016; Weiss et al., 2016) and in mountain wave ice PSCs (Carslaw et al., 2002; Fueglistaler et al., 2002; Luo et al., 2003; Voigt et al., 2003). Vice versa, we find here that ice (re)nucleates on NAT. The NAT particles may have nucleated on STS with meteoric dust (Voigt et al., 2005; Hoyle et al., 2013) or in mountain wave ice PSCs. The pathway of ice nucleation on NAT may also be responsible for the early onset of ice PSC formation in December 2015, as observed from the CALIPSO satellite. Further it could be dominant in the Antarctic winter stratosphere, where large-scale low temperatures promote the formation of widespread NAT and ice clouds. Direct laboratory measurements of the nucleation rate of ice on NAT are missing (Koop et al., 1997) and would be required to help to consolidate the suggested ice formation process.

8 Extended Arctic ice PSCs - Implications for Arctic ozone loss and markers for low polar stratospheric winter temperatures

In the Arctic winter 2015/16, ice PSCs first formed in December 2016 and remained for more than a month. Due to their early winter occurrence, their persistence and their large surface areas, Arctic ice PSCs contribute to chlorine processing and polar ozone loss in winter 2015/16. In addition, ice PSCs serve as efficient transporters for nitric acid. NAT is stable below $\mathrm{T}_{\text {ice }}$ and NAT can be included in ice particles. The large ice particles sediment faster and therefore lead to efficient denitrification at PSC altitudes. This slows down the passivation of active chlorine species and further enhances ozone loss. 
Atmos. Chem. Phys. Discuss., doi:10.5194/acp-2016-1082, 2016

Manuscript under review for journal Atmos. Chem. Phys.

Published: 12 December 2016

(c) Author(s) 2016. CC-BY 3.0 License.

Detailed modeling as for example done by Nakajima et al. (2016) for the 2009/2010 winter would help to quantify the contribution of ice PSCs to Arctic 2015/16 ozone loss.

\section{Arctic ice PSCs as markers for low polar stratospheric winter temperatures}

Both, polar ozone trends (Stolarski et al., 2006) and polar temperature trends (Randel et al., 2016) are highly uncertain. Globally averaged, the stratosphere has cooled over the last 3-4 decades (Thompson et al., 2012; Ramaswamy et al., 2006), with an initially stronger, later less pronounced cooling trend. The cooling has been attributed to natural influences and climate change (Ramaswamy et al., 2006) including the effects of increasing greenhouse gases and stratospheric ozone depletion. Due to complex interplay of radiative and dynamic forcings, the trend is less clear in the polar winter stratosphere (Bohlinger et al., 2014), if existing at all (Randel et al., 2016; Thompson et al., 2012). As the mean Arctic winter conditions are at the threshold of ice formation, Arctic ice PSCs are a sensitive marker for low Arctic stratospheric winter temperatures. Therefore, future observations of Arctic ice PSCs may serve as indicator to assess Arctic stratospheric winter temperature and ozone trends.

\section{References}

Bohlinger, P., Sinnhuber, B. M., Ruhnke, R., and Kirner, O.: Radiative and dynamical contributions to past and future Arctic stratospheric temperature trends, Atmos Chem Phys, 14, 1679-1688, 10.5194/acp14-1679-2014, 2014.

Carslaw, K. S., Kettleborough, J. A., Northway, M. J., Davies, S., Gao, R. S., Fahey, D. W., Baumgardner, D. G., Chipperfield, M. P., and Kleinbohl, A.: A vortex-scale simulation of the growth and sedimentation of large nitric acid hydrate particles, J Geophys Res-Atmos, 107, 10.1029/2001jd000467, 2002.

Crutzen, P. J., and Arnold, F.: Nitric-Acid Cloud Formation in the Cold Antarctic Stratosphere - a Major 
Curtius, J., Weigel, R., Vossing, H. J., Wernli, H., Werner, A., Volk, C. M., Konopka, P., Krebsbach, M., Schiller, C., Roiger, A., Schlager, H., Dreiling, V., and Borrmann, S.: Observations of meteoric material and implications for aerosol nucleation in the winter Arctic lower stratosphere derived from in situ particle measurements, Atmos Chem Phys, 5, 3053-3069, 2005.

Cziczo, D. J., Thomson, D. S., and Murphy, D. M.: Ablation, flux, and atmospheric implications of meteors inferred from stratospheric aerosol, Science, 291, 1772-1775, DOI 10.1126/science.1057737, 2001.

Dee, D. P., Uppala, S. M., Simmons, A. J., Berrisford, P., Poli, P., Kobayashi, S., Andrae, U., Balmaseda, M. A., Balsamo, G., Bauer, P., Bechtold, P., Beljaars, A. C. M., van de Berg, L., Bidlot, J., Bormann, N.,

Delsol, C., Dragani, R., Fuentes, M., Geer, A. J., Haimberger, L., Healy, S. B., Hersbach, H., Holm, E. V., Isaksen, L., Kallberg, P., Kohler, M., Matricardi, M., McNally, A. P., Monge-Sanz, B. M., Morcrette, J. J., Park, B. K., Peubey, C., de Rosnay, P., Tavolato, C., Thepaut, J. N., and Vitart, F.: The ERA-Interim reanalysis: configuration and performance of the data assimilation system, Q J Roy Meteor Soc, 137, 553597, 10.1002/qj.828, 2011.

Dörnbrack, A., Birner, T., Fix, A., Flentje, H., Meister, A., Schmid, H., Browell, E. V., and Mahoney, M. J.: Evidence for inertia gravity waves forming polar stratospheric clouds over Scandinavia, J Geophys Res-Atmos, 107, 10.1029/2001jd000452, 2002.

Dörnbrack, A., Gisinger, S., Pitts, M. C., Poole, L. R., and Maturilli, M.: Multilevel cloud structures over Svalbard, Monthly Weather Review, 10.1175/mwr-d-16-0214.1, 2016.

Draxler, R. R., and G. D. Hess: An overview of the HYSPLIT4 modeling system of trajectories, dispersion, and deposition, Aust. Meteor. Mag., 47, 295-308, 1998.

Drdla, K., and Müller, R.: Temperature thresholds for chlorine activation and ozone loss in the polar stratosphere, Ann Geophys-Germany, 30, 1055-1073, 10.5194/angeo-30-1055-2012, 2012. 
Atmos. Chem. Phys. Discuss., doi:10.5194/acp-2016-1082, 2016

Manuscript under review for journal Atmos. Chem. Phys.

Published: 12 December 2016

(c) Author(s) 2016. CC-BY 3.0 License.

Dye, J. E., Baumgardner, D., Gandrud, B. W., Kawa, S. R., Kelly, K. K., Loewenstein, M., Ferry, G. V., and Freezing of Sulfuric-Acid Droplets, and Implications for Cloud Formation, J Geophys Res-Atmos, 97, 8015-8034, 1992.

Engel, I., Luo, B. P., Pitts, M. C., Poole, L. R., Hoyle, C. R., Grooss, J. U., Dornbrack, A., and Peter, T.: Heterogeneous formation of polar stratospheric clouds - Part 2: Nucleation of ice on synoptic scales, Atmos Chem Phys, 13, 10769-10785, 10.5194/acp-13-10769-2013, 2013.

Esselborn, M., M. Wirth, A. Fix, M. Tesche, and G. Ehret: Airborne high spectral resolution lidar for measuring aerosol extinction and backscatter coefficients, Applied Optics, 47, 346-358, 10.1364/AO.47.000346, 2008.

Fahey, D. W., Gao, R. S., Carslaw, K. S., Kettleborough, J., Popp, P. J., Northway, M. J., Holecek, J. C., Ciciora, S. C., McLaughlin, R. J., Thompson, T. L., Winkler, R. H., Baumgardner, D. G., Gandrud, B., Wennberg, P. O., Dhaniyala, S., McKinney, K., Peter, T., Salawitch, R. J., Bui, T. P., Elkins, J. W., Webster, C. R., Atlas, E. L., Jost, H., Wilson, J. C., Herman, R. L., Kleinbohl, A., and von Konig, M.: The detection of large HNO3-containing particles in the winter arctic stratosphere, Science, 291, 10261031, DOI 10.1126/science.1057265, 2001.

Farman, J. C., Gardiner, B. G., and Shanklin, J. D.: Large losses of total ozone in Antarctica reveal seasonal ClO_x/NO_x interaction, Nature, 315, 207-210, 1985.

Freudenthaler, V., Esselborn, M., Wiegner, M., Heese, B., Tesche, M., Ansmann, A., Müller, D., Althausen, D., Wirth, M., Fix, A., Ehret, G., Knippertz, P., Toledano, C., Gasteiger, J., Garhammer, M. and Seefeldner, M. (2009), Depolarization ratio profiling at several wavelengths in pure Saharan dust during SAMUM 2006. Tellus B, 61: 165-179. doi:10.1111/j.1600-0889.2008.00396.x 
Atmos. Chem. Phys. Discuss., doi:10.5194/acp-2016-1082, 2016

Fueglistaler, S., Luo, B. P., Buss, S., Wernli, H., Voigt, C., Muller, M., Neuber, R., Hostetler, C. A., Poole, L. R., Flentje, H., Fahey, D. W., Northway, M. J., and Peter, T.: Large NAT particle formation by mother clouds: Analysis of SOLVE/THESEO-2000 observations, Geophysical Research Letters, 29, 10.1029/2001gl014548, 2002.

Gao, R. S., Gierczak, T., Thornberry, T. D., Rollins, A. W., Burkholder, J. B., Telg, H., Voigt, C., Peter, T., and Fahey, D. W.: Persistent Water-Nitric Acid Condensate with Saturation Water Vapor Pressure Greater than That of Hexagonal Ice, J Phys Chem A, 120, 1431-1440, 10.1021/acs.jpca.5b06357, 2016.

Grooß, J. U., Gunther, G., Muller, R., Konopka, P., Bausch, S., Schlager, H., Voigt, C., Volk, C. M., and Toon, G. C.: Simulation of denitrification and ozone loss for the Arctic winter 2002/2003, Atmos Chem Phys, 5, 1437-1448, 2005.

Groß, S., Wirth, M., Schäfler, A., Fix, A., Kaufmann, S., and Voigt, C.: Potential of airborne lidar measurements for cirrus cloud studies, Atmos. Meas. Tech., 7, 2745-2755, 10.5194/amt-7-2745-2014, 2014.

Hanson, D., and Mauersberger, K.: Laboratory Studies of the Nitric-Acid Trihydrate - Implications for the South Polar Stratosphere, Geophysical Research Letters, 15, 855-858, Doi 10.1029/Gl015i008p00855, 1988.

Hanson, D. R., and Ravishankara, A. R.: Investigation of the Reactive and Nonreactive Processes Involving ClONO2 and $\mathrm{HCl}$ on Water and Nitric Acid Doped Ice, J Phys Chem-Us, 96, 2682-2691, Doi 10.1021/J100185a052, 1992.

Hoyle, C. R., Engel, I., Luo, B. P., Pitts, M. C., Poole, L. R., Grooss, J. U., and Peter, T.: Heterogeneous formation of polar stratospheric clouds - Part 1: Nucleation of nitric acid trihydrate (NAT), Atmos Chem Phys, 13, 9577-9595, 10.5194/acp-13-9577-2013, 2013. 
Atmos. Chem. Phys. Discuss., doi:10.5194/acp-2016-1082, 2016

Manuscript under review for journal Atmos. Chem. Phys.

Published: 12 December 2016

(c) Author(s) 2016. CC-BY 3.0 License.

Iannarelli, R., and Rossi, M. J.: The mid-IR Absorption Cross Sections of alpha- and beta-NAT (HNO3 * $3 \mathrm{H} 2 \mathrm{O}$ ) in the range 170 to $185 \mathrm{~K}$ and of metastable NAD (HNO3 * 2H2O) in the range 172 to $182 \mathrm{~K}, \mathrm{~J}$ Geophys Res-Atmos, 120, 10.1002/2015JD023903, 2015.

Kawa, S. R., Stolarski, R. S., Newman, P. A., Douglass, A. R., Rex, M., Hofmann, D. J., Santee, M. L., and Frieler, K.: Sensitivity of polar stratospheric ozone loss to uncertainties in chemical reaction kinetics, Atmos. Chem. Phys., 9, 8651-8660, doi:10.5194/acp-9-8651-2009, 2009.

Koop, T., Carslaw, K. S., and Peter, T.: Thermodynamic stability and phase transitions of PSC particles, Geophysical Research Letters, 24, 2199-2202, Doi 10.1029/97gl02148, 1997.

Koop, T., Luo, B., Tsias, A., and Peter, T.: Water activity as the determinant for homogeneous ice nucleation in aqueous sloutions, Nature, 406, 611-614, 10.1038/35020537, 2000.

Luo, B. P., Voigt, C., Fueglistaler, S., and Peter, T.: Extreme NAT supersaturations in mountain wave ice PSCs: A clue to NAT formation, J Geophys Res-Atmos, 108, Artn 4441

10.1029/2002jd003104, 2003.

Manney, G., and Lawrence, Z. D.: The major stratospheric final warming in 2016: Dispersal of vortex air and termination of Arctic chemical ozone loss, accepted for Atmos. Chem. Phys., , 1-40, 10.5194/acp2016-633, 2016.

Manney, G. L., Santee, M. L., Rex, M., Livesey, N. J., Pitts, M. C., Veefkind, P., Nash, E. R., Wohltmann, I., Lehmann, R., Froidevaux, L., Poole, L. R., Schoeberl, M. R., Haffner, D. P., Davies, J., Dorokhov, V., Gernandt, H., Johnson, B., Kivi, R., Kyro, E., Larsen, N., Levelt, P. F., Makshtas, A., McElroy, C. T., Nakajima, H., Parrondo, M. C., Tarasick, D. W., von der Gathen, P., Walker, K. A., and

Zinoviev, N. S.: Unprecedented Arctic ozone loss in 2011, Nature, 478, 469-U465, 10.1038/nature10556, 2011. 
Atmos. Chem. Phys. Discuss., doi:10.5194/acp-2016-1082, 2016

Manuscript under review for journal Atmos. Chem. Phys.

Published: 12 December 2016

(c) Author(s) 2016. CC-BY 3.0 License.

Matthias, V., A. Dörnbrack, and G. Stober: The extraordinary strong and cold polar vortex in the early northern winter 2015/16, Geophys. Res. Lett., online, 10.1002/2016GL071676, 2016.

Murphy, D. M., and Koop, T.: Review of the vapour pressures of ice and supercooled water for atmospheric applications, Q. J. R. Meteorol. Soc., 131, 1539-1565, 10.1256/qj.04.94, 2005.

Nakajima, H., Wohltmann, I. , Wegner, T. , Takeda, M. , Pitts, M. C. , Poole, L. R. , Lehmann, R. , Santee, M. L. and Rex, M. (2016): Polar Stratospheric Cloud evolution and chlorine activation measured by CALIPSO and MLS, and modeled by ATLAS , Atmospheric Chemistry and Physics, 16 , 3311-3325, doi: 10.5194/acp-16-3311-2016, 2016.

Peter, T.: Microphysics and heterogeneous chemistry of polar stratospheric clouds, Annu Rev Phys Chem, 48, 785-822, DOI 10.1146/annurev.physchem.48.1.785, 1997.

Pitts, M. C., Poole, L. R., and Thomason, L. W.: CALIPSO polar stratospheric cloud observations: second-generation detection algorithm and composition discrimination, Atmos Chem Phys, 9, 7577-7589, 2009.

Pitts, M. C., Poole, L. R., Dörnbrack, A., and Thomason, L. W.: The 2009-2010 Arctic polar stratospheric cloud season: a CALIPSO perspective, Atmos Chem Phys, 11, 2161-2177, 10.5194/acp-11-2161-2011, 2011.

Pitts, M. C., Poole, L. R., Lambert, A., and Thomason, L. W.: An assessment of CALIOP polar stratospheric cloud composition classification, Atmos Chem Phys, 13, 2975-2988, 10.5194/acp-13-2975$3752013,2013$.

Ramaswamy, V., Schwarzkopf, M. D., Randel, W. J., Santer, B. D., Soden, B. J., and Stenchikov, G. L.: Anthropogenic and natural influences in the evolution of lower stratospheric cooling, Science, 311, 11381141, 10.1126/science.1122587, 2006. 
Atmos. Chem. Phys. Discuss., doi:10.5194/acp-2016-1082, 2016

Manuscript under review for journal Atmos. Chem. Phys.

Published: 12 December 2016

(c) Author(s) 2016. CC-BY 3.0 License.

Randel, W. J., Smith, A. K., Wu, F., Zou, C. Z., and Qian, H. F.: Stratospheric Temperature Trends over 4859, 10.1175/Jcli-D-15-0629.1, 2016.

Schreiner, J., Voigt, C., Kohlmann, A., Arnold, F., Mauersberger, K., and Larsen, N.: Chemical Analysis of Polar Stratospheric Cloud Particles, Science, 283, 968-970, 10.1126/science.283.5404.968, 1999.

J. Schreiner, C. Voigt, C. Weisser, A. Kohlmann, K. Mauersberger, T. Deshler, C. Kröger, J. Rosen, N.

Kjome, N. Larsen, A. Adriani, F. Cairo, G. Di Donfrancesco, J. Ovarlez, H. Ovarlez, and A. Dörnbrack: Chemical, microphysical, and optical properties of polar stratospheric clouds, J. Geophys. Res., 107, 8313, doi:10.1029/2001JD00082, 2002.

Sinnhuber, B. M., Stiller, G., Ruhnke, R., von Clarmann, T., Kellmann, S., and Aschmann, J.: Arctic winter 2010/2011 at the brink of an ozone hole, Geophysical Research Letters, 38, Artn L24814 10.1029/2011gl049784, 2011

Solomon, S., Garcia, R. R., Rowland, F. S., and Wuebbles, D. J.: On the Depletion of Antarctic Ozone, Nature, 321, 755-758, Doi 10.1038/321755a0, 1986.

Solomon, S.: The hole truth - What's news (and what's not) about the ozone hole., Nature, 427, 289-291, 10.1038/427289a, 2004.

Stolarski, R. S., Douglass, A. R., Steenrod, S., and Pawson, S.: Trends in stratospheric ozone: Lessons learned from a 3D chemical transport model, J Atmos Sci, 63, 1028-1041, Doi 10.1175/Jas3650.1, 2006.

Thompson, D. W. J., Seidel, D. J., Randel, W. J., Zou, C. Z., Butler, A. H., Mears, C., Osso, A., Long, C., and Lin, R.: The mystery of recent stratospheric temperature trends, Nature, 491, 692-697, 10.1038/nature11579, 2012. 
Atmos. Chem. Phys. Discuss., doi:10.5194/acp-2016-1082, 2016

Toon, O. B., Turco, R. P., Jordan, J., Goodman, J., and Ferry, G.: Physical Processes in Polar Stratospheric Ice Clouds, J Geophys Res-Atmos, 94, 11359-11380, Doi 10.1029/Jd094id09p11359, 1989.

Toon, O. B., Tabazadeh, A., Browell, E. V., and Jordan, J.: Analysis of lidar observations of Arctic polar stratospheric clouds during January 1989, J Geophys Res-Atmos, 105, 20589-20615, Doi 10.1029/2000jd900144, 2000.

Voigt, C., Schreiner, J., Kohlmann, A., Zink, P., Mauersberger, K., Larsen, N., Deshler, T., Kroger, C., Rosen, J., Adriani, A., Cairo, F., Di Donfrancesco, G., Viterbini, M., Ovarlez, J., Ovarlez, H., David, C., and Dörnbrack, A.: Nitric Acid Trihydrate (NAT) in Polar Stratospheric Clouds, Science, 290, 17561758, 10.1126/science.290.5497.1756, 2000.

Voigt, C., Larsen, N., Deshler, T., Kroger, C., Schreiner, J., Mauersberger, K., Luo, B. P., Adriani, A.,

Cairo, F., Di Donfrancesco, G., Ovarlez, J., Ovarlez, H., Dornbrack, A., Knudsen, B., and Rosen, J.: In situ mountain-wave polar stratospheric cloud measurements: Implications for nitric acid trihydrate formation, J Geophys Res-Atmos, 108, 10.1029/2001jd001185, 2003.

Voigt, C., Schlager, H., Luo, B. P., Dörnbrack, A., Roiger, A., Stock, P., Curtius, J., Vössing, H., Borrmann, S., Davies, S., Konopka, P., Schiller, C., Shur, G., and Peter, T.: Nitric Acid Trihydrate (NAT) formation at low NAT supersaturation in Polar Stratospheric Clouds (PSCs), Atmos. Chem. Phys., 5, 1371-1380, doi:10.5194/acp-5-1371-2005, 2005.

von Hobe, M., Bekki, S., Borrmann, S., Cairo, F., D'Amato, F., Di Donfrancesco, G., Dornbrack, A., Ebersoldt, A., Ebert, M., Emde, C., Engel, I., Ern, M., Frey, W., Genco, S., Griessbach, S., Grooss, J. U., Gulde, T., Gunther, G., Hosen, E., Hoffmann, L., Homonnai, V., Hoyle, C. R., Isaksen, I. S. A., Jackson,

D. R., Janosi, I. M., Jones, R. L., Kandler, K., Kalicinsky, C., Keil, A., Khaykin, S. M., Khosrawi, F., Kivi, R., Kuttippurath, J., Laube, J. C., Lefevre, F., Lehmann, R., Ludmann, S., Luo, B. P., Marchand, M., Meyer, J., Mitev, V., Molleker, S., Muller, R., Oelhaf, H., Olschewski, F., Orsolini, Y., Peter, T., Pfeilsticker, K., Piesch, C., Pitts, M. C., Poole, L. R., Pope, F. D., Ravegnani, F., Rex, M., Riese, M., 
Atmos. Chem. Phys. Discuss., doi:10.5194/acp-2016-1082, 2016

Rockmann, T., Rognerud, B., Roiger, A., Rolf, C., Santee, M. L., Scheibe, M., Schiller, C., Schlager, H., de Cumis, M. S., Sitnikov, N., Sovde, O. A., Spang, R., Spelten, N., Stordal, F., Suminska-Ebersoldt, O., Ulanovski, A., Ungermann, J., Viciani, S., Volk, C. M., Scheidt, M. V., von der Gathen, P., Walker, K., Wegner, T., Weigel, R., Weinbruch, S., Wetzel, G., Wienhold, F. G., Wohltmann, I., Woiwode, W., Young, I. A. K., Yushkov, V., Zobrist, B., and Stroh, F.: Reconciliation of essential process parameters for an enhanced predictability of Arctic stratospheric ozone loss and its climate interactions (RECONCILE): activities and results, Atmos Chem Phys, 13, 9233-9268, 10.5194/acp-13-9233-2013, 2013.

Weiss, F., Kubel, F., Galvez, O., Hoelzel, M., Parker, S. F., Baloh, P., Iannarelli, R., Rossi, M. J., and Grothe, H.: Metastable Nitric Acid Trihydrate in Ice Clouds, Angew Chem Int Edit, 55, 3276, 10.1002/anie.201510841, 2016.

Weigel, R., Volk, C. M., Kandler, K., Hösen, E., Günther, G., Vogel, B., Grooß, J.-U., Khaykin, S., Belyaev, G. V., and Borrmann, S.: Enhancements of the refractory submicron aerosol fraction in the Arctic polar vortex: feature or exception?, Atmos. Chem. Phys., 14, 12319-12342, doi:10.5194/acp-14-12319-2014, 2014.

Wirth, M., Fix, A., Mahnke, P., Schwarzer, H., Schrandt, F., and Ehret, G.: The airborne muli-wavelength water vapor differential absorption lidar WALES: system design and performance, Appl. Phys. B, 96, 201 - 213, 2010.

Wohltmann, I., Wegner, T., Muller, R., Lehmann, R., Rex, M., Manney, G. L., Santee, M. L., Bernath, P., Suminska-Ebersoldt, O., Stroh, F., von Hobe, M., Volk, C. M., Hosen, E., Ravegnani, F., Ulanovsky, A., and Yushkov, V.: Uncertainties in modelling heterogeneous chemistry and Arctic ozone depletion in the winter 2009/2010, Atmos Chem Phys, 13, 3909-3929, 10.5194/acp-13-3909-2013, 2013. 
Atmos. Chem. Phys. Discuss., doi:10.5194/acp-2016-1082, 2016

Woiwode, W., Grooss, J. U., Oelhaf, H., Molleker, S., Borrmann, S., Ebersoldt, A., Frey, W., Gulde, T., Khaykin, S., Maucher, G., Piesch, C., and Orphal, J.: Denitrification by large NAT particles: the impact of reduced settling velocities and hints on particle characteristics, Atmos Chem Phys, 14, 11525-11544, 10.5194/acp-14-11525-2014, 2014.

Zondlo, M. A., Hudson, P. K., Prenni, A. J., and Tolbert, M. A.: Chemistry and microphysics of polar stratospheric clouds and cirrus clouds, Annu Rev Phys Chem, 51, 473-499, DOI 10.1146/annurev.physchem.51.1.473, 2000.

Acknowledgements: We thank the DLR flight department for excellent support of the campaign. Further we thank H. Ziereis, T. Jurkat, S. Kaufmann and M. Dameris for helpful comments on the manuscript. The observational data are available at https://halo-db.pa.op.dlr.de. Meteorological data are achieved in the MARS archive at ECMWF. Support for the campaign was provided by the Deutsche Forschungsgemeinschaft DFG via the HALO-SPP 1294 program and the Helmholtz society via the ATMO program. CV has been funded by the Helmholtz society under contact no W2/W3-060 and by DFG contract no VO1504/4-1, BE by DFG contract no DO1400/6-1. Support for MP and LP is provided by the NASA CALIPSO/CloudSat Science Team.

$\mathrm{CV}$ performed the scientific study and wrote the paper. $\mathrm{AD}$ and $\mathrm{BE}$ analyzed the meteorological conditions for the Arctic winter 2016. MW and SG performed the HALO lidar measurements and data evaluation. MP and LP evaluated CALIPSO data. RB made the HYSPLIT trajectory calculations. BMS and HO led the POLSTRACC campaign. All authors contributed to the manuscript. The authors declare that they have no conflict of interest. 
Atmos. Chem. Phys. Discuss., doi:10.5194/acp-2016-1082, 2016

Manuscript under review for journal Atmos. Chem. Phys.

Published: 12 December 2016

(c) Author(s) 2016. CC-BY 3.0 License.
Atmospheric

Chemistry

and Physics

Discussions
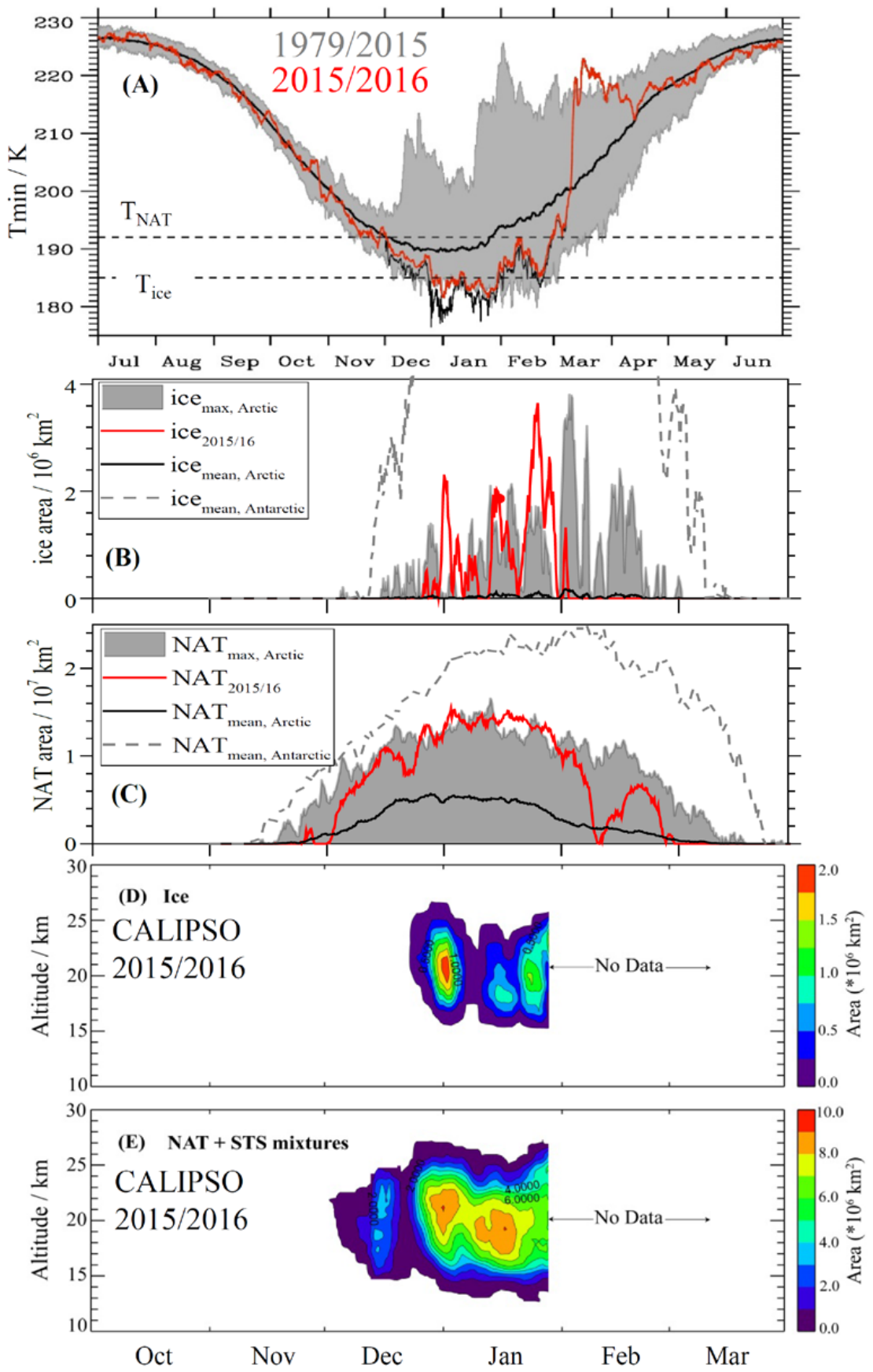
Atmos. Chem. Phys. Discuss., doi:10.5194/acp-2016-1082, 2016

Figure 1 Temperature evolution of the 2015/16 Arctic winter stratosphere (A) Temperature evolution of the polar stratosphere derived from European Centre for Medium-Range Weather Forecasts ECMWF meteorological data (ERA interim climatology, $1^{\circ} \times 1^{\circ}$ resolution). Thick black line: Mean of the minimum polar cap temperatures $\mathrm{T}_{\min }(\mathrm{K})$ for $\varphi>65^{\circ} \mathrm{N}$ at $30 \mathrm{hPa}$ between 1979 and 2015. The gray shading indicates the temperature range of $\mathrm{T}_{\min }$ at the same pressure level throughout the 36-years data record. The red line shows the evolution of $\mathrm{T}_{\min }$ in the Arctic winter 2015/16, decreasing below the 36years data record throughout January 2016. The thin black line gives results from the higher resolution $\left(0.25^{\circ} \times 0.25^{\circ}\right)$ integrated forecast system IFS. $\mathrm{T}_{\text {ice }}$ (Murphy and Koop, 2005) and $\mathrm{T}_{\mathrm{NAT}}$ (Hanson and Mauersberger, 1988) are calculated using 4.6 ppmv $\mathrm{H}_{2} \mathrm{O}$ and 7 ppbv $\mathrm{HNO}_{3}$ for Fig. 1 and Fig. 4, relevant for the 2015/16 Arctic vortex conditions (Manney and Lawrence, 2016). (B) Evolution of the Arctic vortex area with temperatures below $\mathrm{T}_{\text {ice. }}$. Black line: Mean area below $\mathrm{T}_{\text {ice }}\left(\mathrm{A}_{\mathrm{icc}}\right)$ at $30 \mathrm{hPa}$ pressure ( 21.6 km) between 1979 and 2015. The gray shading indicates maximum and minimum areas below $\mathrm{T}_{\text {ice }}$ in the same time period. The red line shows the evolution of $\mathrm{A}_{\text {ice }}$ at the $30 \mathrm{hPa}$ pressure surface in the Arctic winter 2015/16. Gray dashed line: Mean area below $\mathrm{T}_{\text {ice }}$ at $30 \mathrm{hPa}$ south of $65^{\circ} \mathrm{S}$ from 1979 to 2015, shifted by 6 months to account for seasonality. (C) Same data for NAT. (D) Altitude and occurrence of ice PSCs detected by the lidar onboard CALIPSO satellite using the classification from (Pitts et al., 2009). (E) Altitude and occurrence NAT/STS PSCs measured with CALIOP.

Extremely low temperatures and large areas with temperatures below $T_{\text {ice }}$ and $T_{\mathrm{NAT}}$ were encountered in the exceptional Arctic winter 2015/16. Synoptic ice PSCs were observed by CALIOP from mid of December 2015 till end of January 2016. 
Atmos. Chem. Phys. Discuss., doi:10.5194/acp-2016-1082, 2016

Manuscript under review for journal Atmos. Chem. Phys.

Published: 12 December 2016

(C) Author(s) 2016. CC-BY 3.0 License.
Atmospheric

Chemistry

and Physics

Discussions

(c) (1)
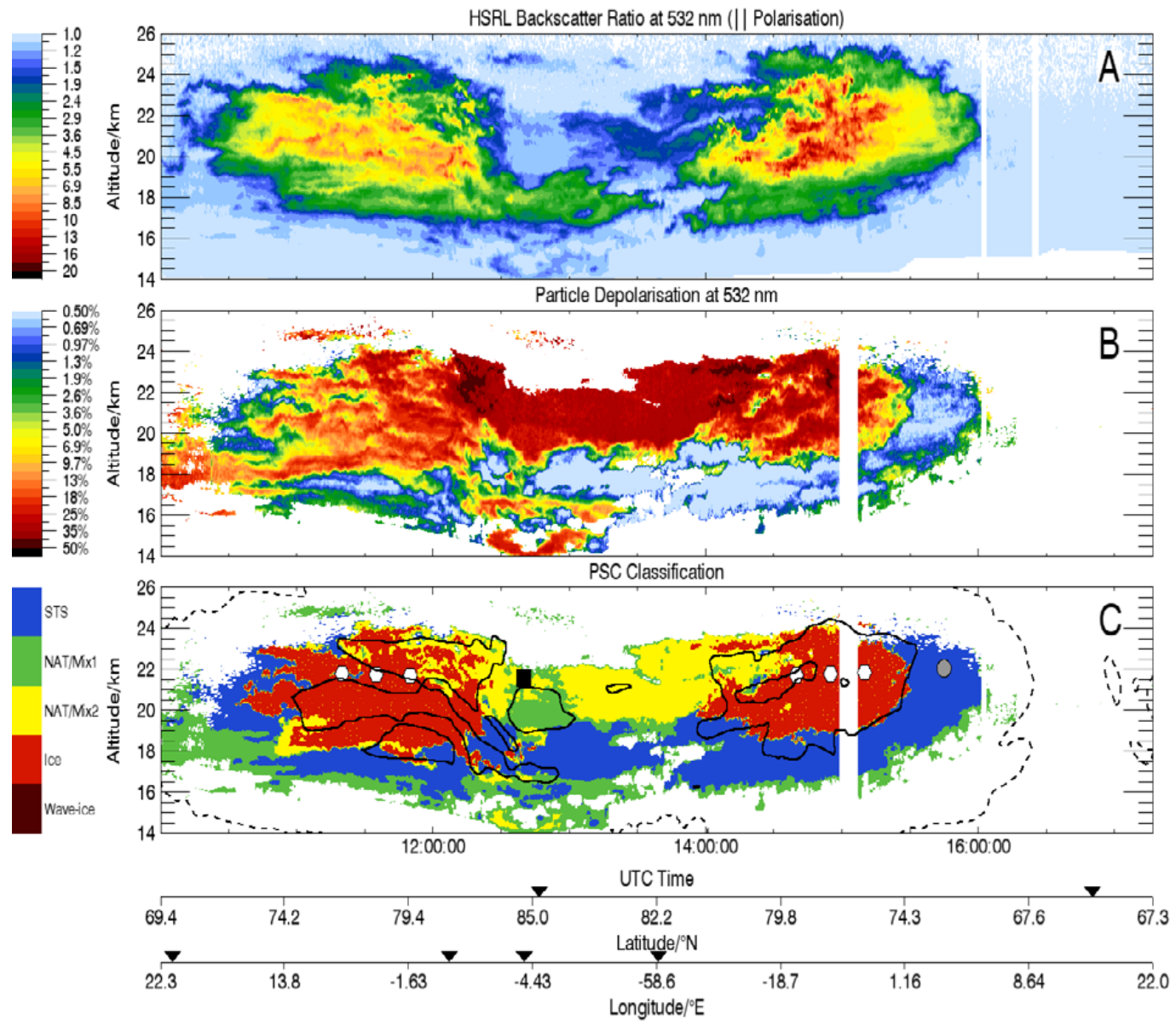

Figure 2 Lidar observation of synoptic-scale polar stratospheric ice clouds (A) Backscatter ratios

from the WALES high spectral resolution lidar (Wirth et al., 2010) at $532 \mathrm{~nm}$ wavelengths during a

HALO flight into the Arctic vortex on 22 January 2016. Combined with information on particle depolarization (B), the PSC type (panel C) can be inferred (see also Fig.3). A PSC extends between 16 and $24 \mathrm{~km}$. Its core contains a thick synoptic ice PSC (red area in panel C) extending over several hundred $\mathrm{km}$ from $73^{\circ} \mathrm{N}$ to $82^{\circ} \mathrm{N}$ along the HALO flight track. The ice PSC is embedded in NAT layers (NAT/MIX1, green; NAT/MIX2, yellow) and in liquid STS layers (blue). In addition, the areas with temperatures below $\mathrm{T}_{\mathrm{NAT}}$ (dashed line) and $\mathrm{T}_{\text {ice }}$ (solid line) as derived from ECMWF temperatures and water vapor fields and a climatological $\mathrm{HNO}_{3}$ profile, are shown in panel C. A major fraction of the ice 
Atmos. Chem. Phys. Discuss., doi:10.5194/acp-2016-1082, 2016

Manuscript under review for journal Atmos. Chem. Phys.

Published: 12 December 2016

(c) Author(s) 2016. CC-BY 3.0 License.

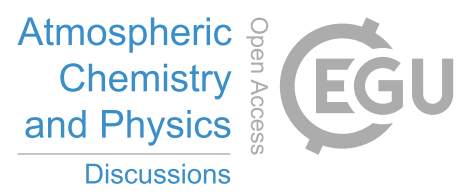

(c) (i)

cloud is observed at $\mathrm{T}<\mathrm{T}_{\text {ice. }}$. The NAT/MIX2 layer could also contain ice particles where temperatures are below $\mathrm{T}_{\text {ice. }}$. The ending points of the trajectories given in Fig. 4 for ice (white hexagon), NAT (black square) and STS (gray circle) are also shown. 
Atmos. Chem. Phys. Discuss., doi:10.5194/acp-2016-1082, 2016

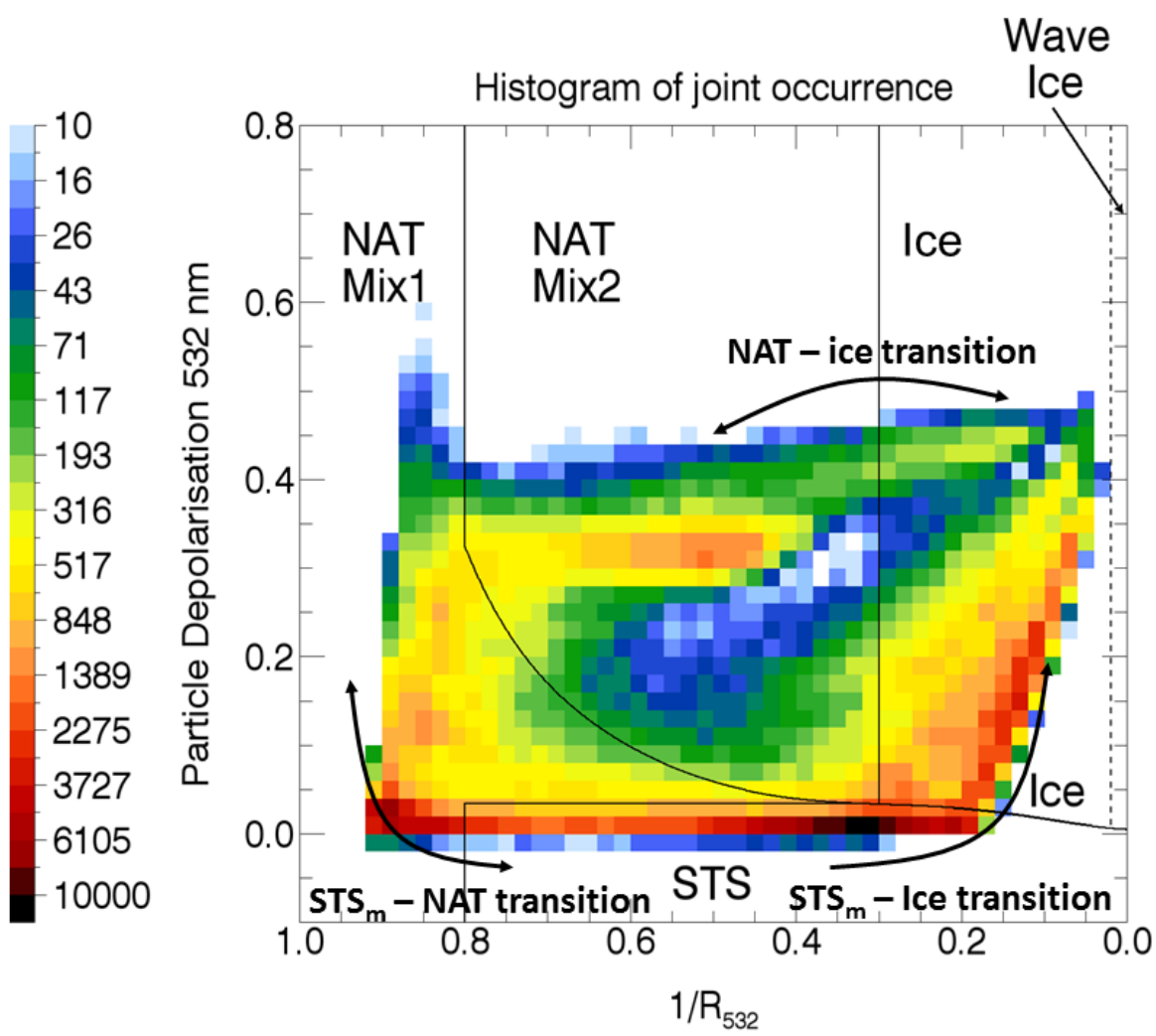

Figure 3 Classification of the 22 January 2016 PSC Composite 2-D histogram of the PSC shown in Fig. 2 in the aerosol-depolarization vs. 1/backscatter ratio coordinate system. The solid black lines denote the boundaries of the PSC composition domains defined by Pitts et al. (2011) with new boundary between ice and NAT/Mix2 of 0.3. The histogram bin size is $0.02 \times 0.02$ and the color scale indicates the number of cloud observations (4 km horizontal by $100 \mathrm{~m}$ vertical) falling within each bin. No observation falls into the wave ice class formed in strong mountain waves. $\mathrm{STS}_{\mathrm{m}}$ denotes STS with meteoric dust inclusions. The $\mathrm{STS}_{\mathrm{m}}-\mathrm{NAT}, \mathrm{NAT}-$ ice and $\mathrm{STS}_{\mathrm{m}}$ - ice transitions are indicated by arrows. Different PSCs types can be clearly identified by their optical properties and their formation pathway is indicated. 
Atmos. Chem. Phys. Discuss., doi:10.5194/acp-2016-1082, 2016

Manuscript under review for journal Atmos. Chem. Phys.

Published: 12 December 2016

(c) Author(s) 2016. CC-BY 3.0 License.
Atmospheric

Chemistry and Physics

Discussions

(c) (i)

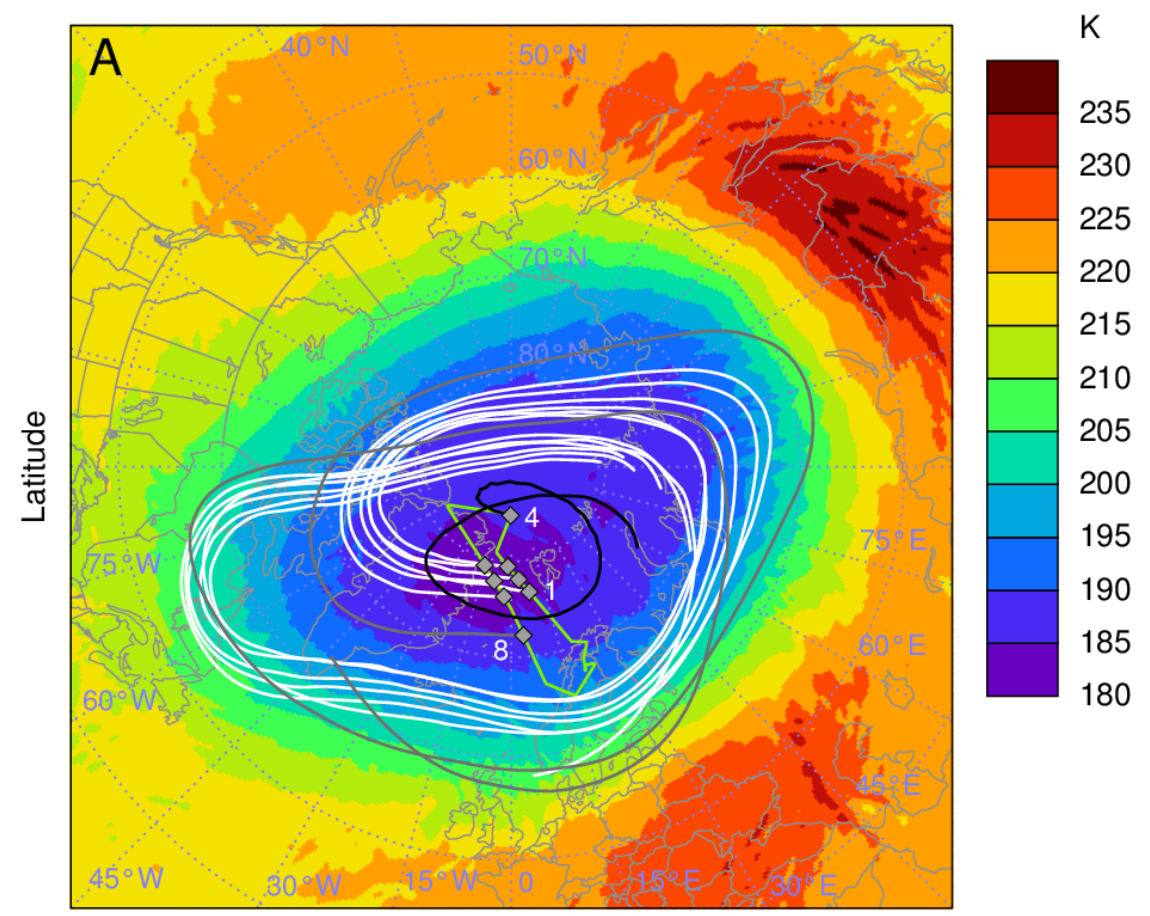

Longitude
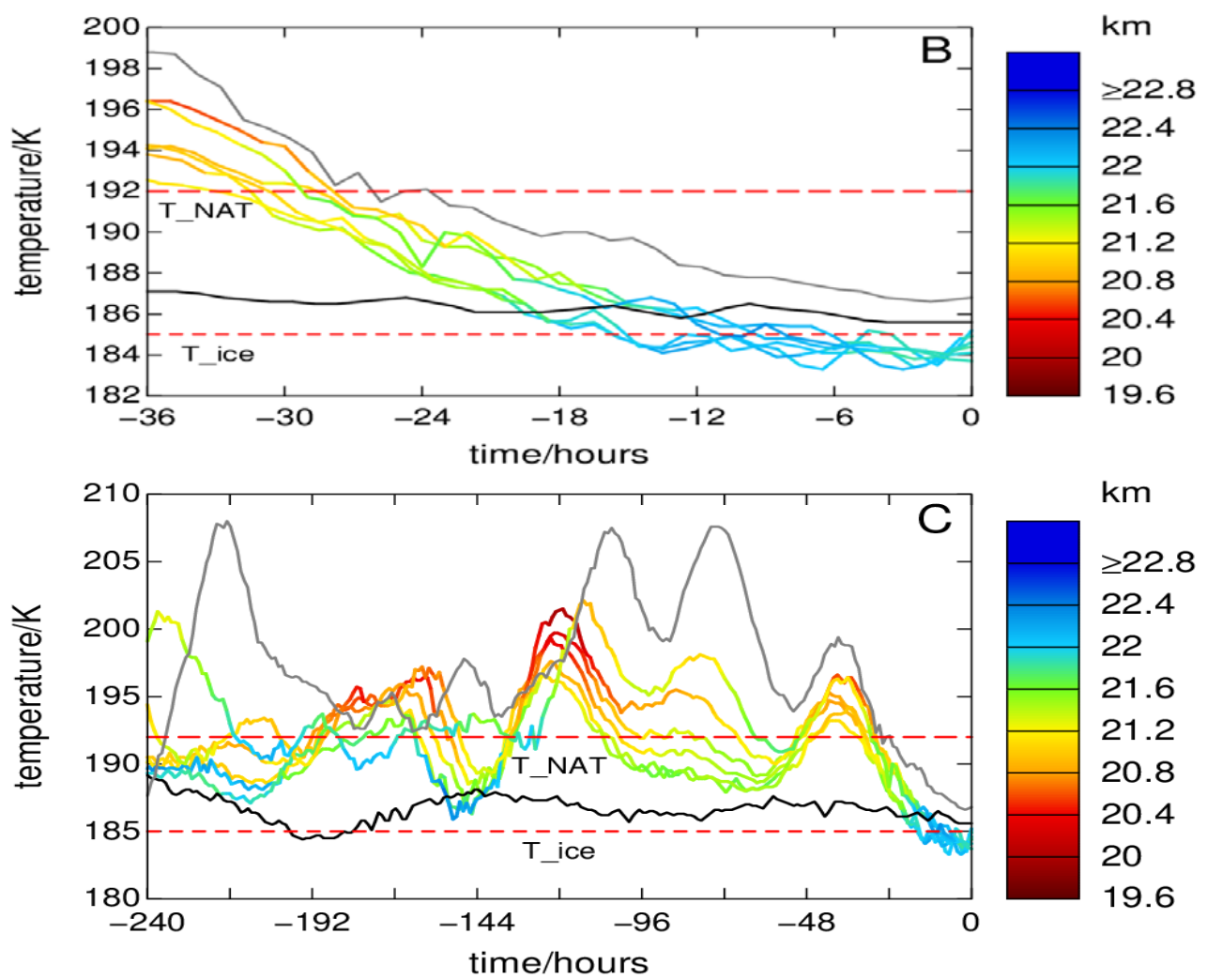

$\mathrm{km}$

$\geq 22.8$

22.4

22

21.6

21.2

20.8

20.4

20

19.6 
Atmos. Chem. Phys. Discuss., doi:10.5194/acp-2016-1082, 2016

Manuscript under review for journal Atmos. Chem. Phys.

Published: 12 December 2016

(c) Author(s) 2016. CC-BY 3.0 License.

Figure 4 Ice formation on NAT (A) Temperatures at 30 hPa on 22 January 2016 derived from ECMWF meteorological data at $0.25^{\circ} \times 0.25^{\circ}$ resolution. The HALO flight track is shown as green line. Temperatures down to $180 \mathrm{~K}$ occurred within the polar vortex. The location of 10-days back-trajectories ending in the ice PSC (numbered chronologically along the flight path 1-3 and 5-7) are shown as white lines, a typical back-trajectory ending in the NAT layer (4) is given in black and for the STS layer (8) in gray. The temperature evolution of 36-h back trajectories ending in the ice (color coded by altitude), NAT, STS (gray) PSC layers at $30 \mathrm{hPa}$ is given in panel (B) and extended to 10 days in panel (C). $\mathrm{T}_{\text {ice }}$ and

$525 \mathrm{~T}_{\mathrm{NAT}}$ are calculated from (Murphy and Koop, 2005) and (Hanson and Mauersberger, 1988), respectively. The trajectories ending in the ice PSC slowly decrease below $\mathrm{T}_{\mathrm{NAT}}$ more than 1 day and below $\mathrm{T}_{\text {ice }}$ about $12 \mathrm{~h}$ prior to the observation. We suggest that the upper part of the ice PSC could have nucleated heterogeneously on pre-existing NAT particles and the lower part on meteoric dust in STS. 